\title{
Risk factors of breast cancer among Iraqi women
}

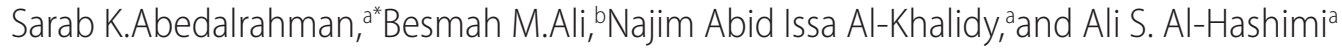

\author{
aWomen Health Center, Al-Alwiyaa Maternity Teaching Hospital, Baghdad, Iraq. \\ bDepartment of Public Health, Ghazi Al-Hariri Hospital for Specialized Surgery, Medical City, Baghdad, Iraq. \\ *Correspondence to Sarab K.Abedalrahman(email: sarab.abedalrahman@yahoo.com). \\ (Submitted:25 December 2018 - Revised version received: 20 January 2019 - Accepted: 25 April 2019 - Published online: 26 June 2019)
}

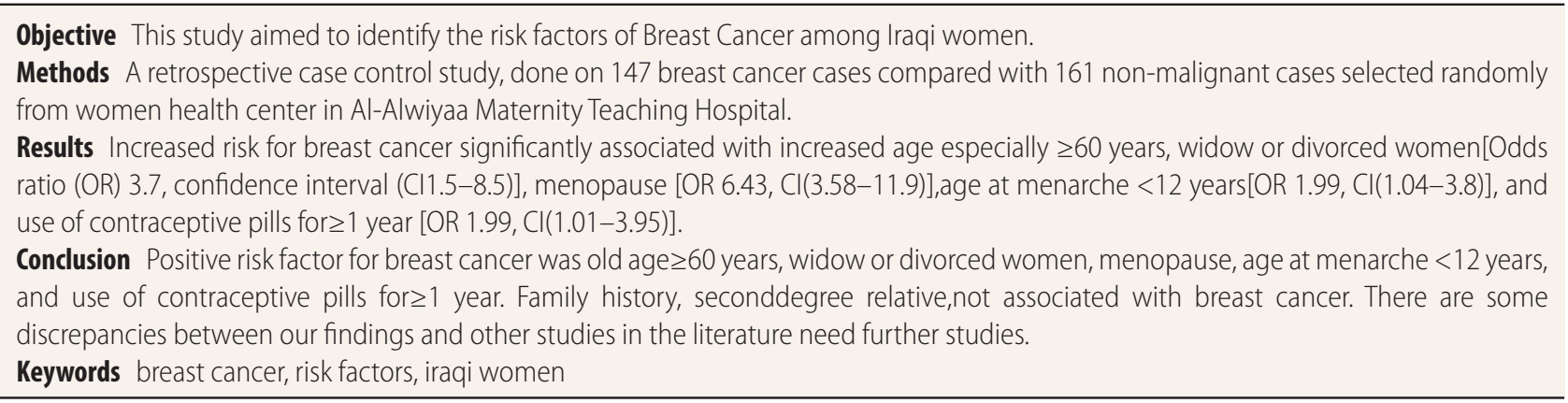

\section{Introduction}

Cancer is anticipated to rise by $70 \%$ in the coming 25 years in the developing countries. Breast cancer is known to represent the main part that increase. ${ }^{1}$ Breast cancer has ranked the first malignancy among the Iraqi population in general and the leading cause of death among women following cardiovascular diseases. ${ }^{2,3}$

Iraqi breast cancer rates were generally constant between 2000 and2009, but newer statistics from the Iraqi Cancer Registry detect increasing rates since 2009 with females over50s causing the main contribution to the increase. ${ }^{4}$

Breast cancer arises from a multifactorial process. Recently, attention was focused on genetic predisposition, and on its association with the modern life style,including diet, alcohol consumption. ${ }^{5}$ Oral contraceptive pills was proved to increase risk of breast cancer, which decrease after stopping it. ${ }^{6}$ These risks are associated with more recent formulations of oral contraceptives.

In Iraq with a huge variation in life style modes, cultural, geographical, diets and habits, there are considerably limited information's sources of on cancer risk factors. Actually, the factors for differences in breast cancer incidence in women are not fully understood, which are likely to be explained by reproductive and lifestyle factors such as literacy, diet, age at menarche and menopause, age at first delivery, abortion, family history of breast cancer. ${ }^{8-10}$

The importance of knowledge of breast cancer risk factors is that it helps in detecting risk group women, and then to use it in the building of breast cancer screening programs and cancer prevention programs. As the risk factors is unique for each community, the study of breast cancer risk factors for Iraqi women will be an important step in planning screening and prevention programs. This study attempts to find out some of the various risk factors of breast cancer among Iraqi women.

\section{Patients and Methods}

A retrospective case control study done on patients attended the women health center, in Al-Alwiyaa Maternity Teaching
Hospital, during the period from January 1, 2018to October 30,2018 . The study sample consists of 147 females proved to have breast cancer by histopathological examination, and 161 patients proved not to have breast cancer by radiological, histopathological, and cytological investigations and considered as a control group.

Data collected through standardized questionnaire to gain information about the personal, demographic characteristics, risk factors for breast cancer (e.g. reproductive, hormonal and genetic). The diagnosis of cases and controls done by consultant medical staff, using a Triple Assessment Technique (i.e. physical breast examination, ultrasonography, with or without mammography and fine needle aspiration cytology) according to the patient state.

The risk factors are asfollows:early age at menarche,late age at menopause, early age at firstpregnancy, and family history, was categorized according to the Centers for Disease Control and Prevention. ${ }^{11}$

The Statistical Package for Social Sciences, version 18 was used for data entry and analysis. Pearson Chi-square $\left(\chi^{2}\right)$ test was used to compare proportions of different factors among different groups of study sample. Odds ratio (OR), and binary univariate logistic regression using Enter method were used to find the associations of risk factors. $P$-value of $\leq 0.05$ was regarded as statistically significant.

\section{Results}

The age distribution show that most of cancer cases were $40-50$ years $(45,30.6 \%)$, and $50-60$ years $(45,30.6 \%)$, versus $<30$ years $(78,48.4 \%)$ among control group, at the same period, this relation was statistically significant as shown in Table 1 . The mean age among cases $50.6 \pm 11.3$, was significantly higher than controls $34.7 \pm 12.3$. The breast cancer starts at the age of 28 years.

Most of the breast cancer cases and controls were from middle socioeconomic state as follows; 104(70.7\%) and 119 (73.9\%) respectively. Estimating the risk using odds ratio 


\begin{tabular}{lccccc}
\hline Table 1 Age distribution of study groups & & & \\
\hline & Cases No (\%) & Controls No (\%) & Total No (\%) & OR (95\%Cl) & P \\
\hline$<30$ years & $6(4.10)$ & $78(48.40)$ & $84(27.30)$ & 1 & $<0.05$ \\
$30-40$ years & $26(17.70)$ & $27(16.80)$ & $53(17.20)$ & 12.519 & $<0.05$ \\
$40-50$ years & $45(30.60)$ & $40(24.80)$ & $85(27.60)$ & 14.625 & $<0.05$ \\
$50-60 y e a r s$ & $45(30.60)$ & $15(9.30)$ & $60(19.50)$ & 39.000 & $<0.05$ \\
$>60$ years & $25(17.60)$ & $1(0.60)$ & $26(8.4)$ & 325.000 & \\
Mean & $50.6 \pm 11.3$ & $34.7 \pm 12.3$ & & &
\end{tabular}

$\chi^{2}=98.7, P<0.05$

demonstrate that socioeconomic state, occupation, and education, were non-significantly associated with breast cancer. However, regarding marital status, when comparing the widow/divorced women to married show [OR 3.7(1.1.5-8.5)], this relation was statistically significant, as shown in Table 2.

The Odds ratio of the menopause was 6.43 , age at menarche 1.99, hormonal contraception use for $\geq 1$ year 1.99 , and menstrual irregularity 1.56 was significantly associated with breast cancer, while age at menopause $\geq 55$ year was non-significantly associated with breast cancer as shown in Table 3 .

The odds ratio for family history of breast cancer was non-significantly associated with breast cancer: family history of breast cancer 0.804 , firstdegree relative 1.036 , firstand seconddegree relative 1.036 , only seconddegree relative 0.56 , one relative 0.82 , two or more relatives 0.73 , as shown in Table 6 .

\section{Discussion}

Breast cancer was reported among females in 20s, which is the same to what reported in previous literatures in Iraq, ${ }^{4,12,13}$ and neighbor countries ${ }^{14}$ but lower than in Cameron 35 years. ${ }^{15}$ This may be due to same environmental exposure.

About $52.4 \%$ of cases aged $<50$ years this figure goes with what reported previously in Iraq, ${ }^{4,12,13}$ and differ from what is known globally that, $75 \%$ of new cases occurs in women aged older than 50 years, ${ }^{16,17}$ this difference indicate presence of an environmental factors.

The early onset of cancer is accompanied by OR increment with increasing age, indicating that factors other than age may affect the breast cancer development. ${ }^{15}$

Most of cases and controls were from middle socioeconomic state $104(70.7 \%), 119$ (73.9\%), respectively,this is similar to previous Iraqi studies, ${ }^{18}$ as most of the Iraqi women were from middle income families and those with high socioeconomic state usually seek the private health care services, that we cannot catch them.

Women are at higher risk of breast cancer with high socioeconomic status of 2.5 -foldthan those from lower socioeconomic level, which is similar to Nkondjock etal., and this may be due to the fact that they tend to carry fewer pregnancies or have children at an older age. ${ }^{19}$

Employed womenhad higher risk of breast cancer of 1.7 than housewives, which agree with Ghiasvand et al. ${ }^{14}$ This may be related to exposure to other risk factors, e.g. carcinogens and stress, as well as they were more educated and had higher socioeconomic status, which by itself risk factors for breast cancer.
Most of the patients were of low educational level, this agree with previous Iraqi studies. ${ }^{13,18,20} \mathrm{High}$ educational level had higher Odds ratiothan low educational level,this goes with Ghiasvand et al. ${ }^{14}$ Those patients were more health education to seek medical counseling.

Menopause had 6.43-fold risk for having breast cancer than menstruating women, goes with what was found in India 1.6-fold, ${ }^{21}$ which was higher than what was found in Iran 0.95 fold, ${ }^{22}$ and Cameron 0.37 -fold. ${ }^{15}$ This may be due to effect of aging as the menopausal women are already old, or to the high postmenopausal blood estrogen levelswhich is established as risk factors. ${ }^{23}$ Sahan et al..$^{24}$ in Iraq documented an increased serum estradiol and prolactin among the pre- and post-menopausal breast cancer women, and recommends emphasizing the necessity of co-operation between the Ministry of Health and the Ministry of Commerce and protecting them from dangerous behavior by providing them with sufficient support and guidance to stay away from the hormonic products and focusing on the extension programs in the protection of the community through educating them with the guidance.

Late menopause increases the risk of breast cancer. Risk increases by almost $3 \%$ for each year older at menopause, so that a women who has the menopause at 55 years rather than 45 years, has approximately $30 \%$ higher risk. ${ }^{25}$ This study revealed that menopause at the age of 55 yearsincreases the risk of breast cancer by twofoldthan those their age of menopause $<55$ years. This is consistent with studies in Morocco(1.36-fold) ${ }^{26}(1.7 \text {-fold })^{27}$ and lower than found by $\mathrm{Al}$ Ramahi ${ }^{28}$ menopause above 50 years had 9.5-fold risk than under 45 years.

This discrepancy may be explained by that most women (especially old age) have difficulties in recalling past events such as age at menarche; therefore, recall bias was unavoidable. ${ }^{13}$

Age at menarche of $<12$ years had twofold risk than at age $\geq 12$ years, this agree with Altaha (3.05). ${ }^{18}$ This result differs from Iranian studies, ${ }^{22,29}$ which revealed 1.5 -fold of risk in women with age at menarche of $<13$ years was fourfold.

Use of hormonal contraceptivepills for 1 year or more, increase the risk bytwofold than non-hormonal contraceptive drugs user, this was supported by the following studies:in China (1992), Norway and Sweden (2002) and Malaysia (2005)..$^{30-32}$ However, anAfrican study show negative association. ${ }^{33}$

Menstrual irregularity was associated with increased risk of breast cancer by 1.6-fold than women with regular menstruation, this finding is consistent with Terry ${ }^{34}$ that irregular menstruation associated with 1.12-fold risk for breast cancer, and other previous studies. ${ }^{35,36}$

While opposed by most of the studies which found inverse effect on breast cancer risk. ${ }^{37-41}$ This increase may be due to use 


\begin{tabular}{|c|c|c|c|c|c|}
\hline & Cases No (\%) & Controls No (\%) & Total No (\%) & OR (95\% Cl) & $P$ \\
\hline \multicolumn{6}{|l|}{ Socioeconomic } \\
\hline Low & $37(25.2)$ & $30(18.60)$ & $67(21.80)$ & 1 & $>0.05$ \\
\hline Middle & $104(70.7)$ & 119(73.90) & $223(72.40)$ & $1.4(0.8-2.5)$ & $>0.05$ \\
\hline High & $6(4.1)$ & $12(7.50)$ & $18(5.80)$ & $2.5(0.8-7.5)$ & $>0.05$ \\
\hline \multicolumn{6}{|l|}{ Marital status } \\
\hline Married & $108(73.5)$ & 127(78.90) & 235 (76.30) & 1.00 & \\
\hline Unmarried & $14(9.50)$ & $26(16.10)$ & $40(13.00)$ & $0.63(0.3-1.5)$ & $>0.05$ \\
\hline Widow/divorced & 25 (18.8) & $8(5.9)$ & 33 (12.3) & $3.7(1.1 .5-8.5)$ & $<0.05$ \\
\hline \multicolumn{6}{|l|}{ Occupation } \\
\hline Housewife & $114(77.60)$ & 137(85.10) & $251(81.50)$ & 1.00 & \\
\hline Employed & $33(22.4)$ & 24(14.9) & $57(18.5)$ & $1.7(0.9-2.9)$ & $>0.05$ \\
\hline \multicolumn{6}{|l|}{ Education } \\
\hline Illiterate & 44 (29.9) & $37(23)$ & $81(26.30)$ & 1.00 & $>0.05$ \\
\hline Primary & 49 (33.3) & 61(37.9) & $110(35.70)$ & $1.5(0.8-2.6)$ & $>0.05$ \\
\hline Intermediate & $24(16.3)$ & $30(18.60)$ & $54(17.50)$ & $1.5(0.7-2.9)$ & $>0.05$ \\
\hline Secondary & $12(8.20)$ & $8(5.00)$ & $20(6.50)$ & $0.8(0.3-2.1)$ & $>0.05$ \\
\hline University & 18 (12.2) & $25(15.50)$ & $43(14.00)$ & $1.7(0.0 .8-3.5)$ & $>0.05$ \\
\hline Total & $147(100)$ & $161(100)$ & $308(100)$ & & \\
\hline
\end{tabular}

\begin{tabular}{|c|c|c|c|c|c|c|}
\hline \multicolumn{2}{|c|}{ Hormonal risk factor } & \multirow{2}{*}{$\begin{array}{c}\text { Cases (\%) } \\
61(41.5)\end{array}$} & \multirow{2}{*}{$\begin{array}{c}\text { Controls (\%) } \\
16(9.90 \%)\end{array}$} & \multirow{2}{*}{$\begin{array}{c}\text { Total (\%) } \\
77(25.00 \%)\end{array}$} & \multirow{3}{*}{$\begin{array}{c}\text { OR (95\% Cl) } \\
6.43(3.58-11.9)\end{array}$} & \multirow{3}{*}{$\begin{array}{c}\boldsymbol{P} \\
<0.05\end{array}$} \\
\hline \multirow{2}{*}{ Menopause } & Yes & & & & & \\
\hline & No & $86(58.50)$ & $145(90.10 \%)$ & $231(75.00 \%)$ & & \\
\hline \multirow{2}{*}{ Age at menarche } & $<12$ & $28(19.00)$ & $17(10.60)$ & $45(14.60)$ & \multirow{2}{*}{$1.99(1.04-3.8)$} & \multirow{2}{*}{$<0.05$} \\
\hline & $\geq 12$ & $119(81.00)$ & $144(89.40)$ & $263(85.40)$ & & \\
\hline \multirow{2}{*}{$\begin{array}{l}\text { Age of meno- } \\
\text { pause }\end{array}$} & $<55$ years & $42(68.90)$ & $13(81.30)$ & $55(71.40)$ & \multirow{2}{*}{$1.96(0.5-7.96)$} & \multirow{2}{*}{$>0.05$} \\
\hline & $\geq 55$ years & $19(31.10)$ & $3(18.80)$ & $22(28.60)$ & & \\
\hline \multirow{2}{*}{ Contraceptive } & $<1$ year & $122(83)$ & $146(90.7)$ & $268(87)$ & \multirow{2}{*}{$1.99(1.01-3.95)$} & \multirow{2}{*}{$<0.05$} \\
\hline & $\geq 1$ year & $25(17.00)$ & $15(9.30)$ & $40(13.00)$ & & \\
\hline \multirow{2}{*}{ Regularity } & Irregular & $22(26.20)$ & $27(18.50)$ & $49(21.30)$ & \multirow{2}{*}{$1.56(0.8-2.96)$} & \multirow{2}{*}{$>0.05$} \\
\hline & Regular & $62(73.80)$ & $119(81.50)$ & $181(78.70)$ & & \\
\hline
\end{tabular}

\begin{tabular}{|c|c|c|c|c|c|c|}
\hline Genetic risk factors & & Cases (\%) & Controls (\%) & Total (\%) & OR $(95 \% \mathrm{Cl})$ & $P$ \\
\hline \multirow{3}{*}{$\begin{array}{l}\text { Family history of breast } \\
\text { cancer }\end{array}$} & Yes & $35(23.80)$ & $45(28.00)$ & $80(26.00)$ & $0.8(0.48-1.34)$ & \\
\hline & No & $112(76.20)$ & $116(72.00)$ & $228(74.00)$ & 1 & $>0.05$ \\
\hline & No relative & $112(76.20)$ & $116(72.00)$ & $228(74.00)$ & 1 & \\
\hline \multirow{4}{*}{ Relative degree } & First degree relative & $17(11.60)$ & $17(10.60)$ & $34(11.00)$ & $1.04(0.5-2.1)$ & $>0.05$ \\
\hline & Second degree relative & $12(8.20)$ & $22(13.70)$ & $34(11.00)$ & $0.56(0.26-1.2)$ & $>0.05$ \\
\hline & First and second degree & $6(4.10)$ & $6(3.70)$ & $12(3.90)$ & $1.036(0.3-3.3)$ & $>0.05$ \\
\hline & 0 & $112(76.20)$ & $116(72.00)$ & $228(74.00)$ & 1 & \\
\hline \multirow[t]{2}{*}{ No. of relatives } & 1 & $28(19.00)$ & $35(21.70)$ & $63(20.50)$ & $0.83(0.47-1.5)$ & $>0.05$ \\
\hline & $\geq 2$ & $7(4.80)$ & $10(6.30)$ & $16(5.20)$ & $0.73(0.3-1.97)$ & $>0.05$ \\
\hline
\end{tabular}


of hormonal therapy for regulation as it was found by Titus-Ernstoff et al..$^{41}$ that the apparent inverse association with irregular menstrual cycles was stronger among women who did not use hormonal replacement therapy.

Positive family history was not significantly associated with increase breast cancerrisk (0.8), while many studies reported the strong association between family history and breast cancer, ${ }^{42}$ in Moroccan two to threefold increased risk, ${ }^{26}$ and in Southern Iran9.07. ${ }^{22,14}$

Family history of the firstdegree relative show increased risk by 1.036 -fold than women without family history of breast cancer, thisagree with a study in Iraq 2.1-fold increase, ${ }^{28}$ and in Cameron 1.3. ${ }^{15}$

Patient with one or more relatives with breast cancer was non-significantly associated with increased risk of breast cancer, this oppositionwhat found by Brewer et al. ${ }^{43}$ in large data base study, a cohort of over 113,000 women from the general UK population, found that one relative with breast cancer history increase the risk by 1.7 times and two or more increase the risk by 2.5 times. And the effect of family history was more prominent in women aged $<45$ years (2.47-fold), while among those aged $>45$ years the risk was 1.63 -fold.The majority of multiple-case families that segregate both breast and ovarian cancer in a dominant fashion are due to mutations in the BRCA1 gene on chromosome $17 \mathrm{q} .{ }^{44}$

This difference may be explained by the presence of other factors that affect both the cases and control groups, in which its effect appear even on the age distribution also, or may be due to having a relative with breast cancer is promoting for seeking health services, which affect our results.

From the results of this study, a need for further investigating the environmental factors that may have direct or indirect effect, on breast cancer, particularly among younger women.

\section{Conclusion and recommendation}

Positive risk factor for breast cancer was $\geq 60$ years of age, widow or divorced women, menopause, age at menarche $<12$ years, and use of contraceptive pills for $\geq 1$ year,family history, seconddegree relative, not associated with breast cancer. There are some discrepancies between our findings and other studies in the literature which necessity need further studies.

\section{Conflicts of Interest}

None.

\section{References}

1. Center M, Rebecca S, Ahmedin J. Global Cancer Facts \& Figures. $2^{\text {nd }}$ Ed. American Cancer Society,Atlanta,2011,1-52.

2. Iraqi Cancer Board. Results of the Iraqi Cancer Registry 2012. Iraqi Cancer Registry Center, Ministry of Health,Baghdad, 2015.

3. Alwan NAS. Breast cancer among Iraqi women: preliminary findings from a Regional Comparative Breast Cancer Research Project. JGlobOncol.2016;2:255-258.

4. Al-Hashimi MM, WangXJ. Breast cancer in Iraq, incidence trends from 2000-2009. Asian PacJCancer Prev.2014;15:281-286.

5. McPherson K, Steel CM, DixonJ. M.. ABC of breast diseases. Breast cancer-epidemiology, risk factors, and genetics. BMJ 2000;321:624-628,

6. Bhupathiraju SN, Grodstein F, Stampfer MJ, Willett WC, Hu FB, Manson JE. Exogenous hormone use: oral contraceptives, postmenopausal hormone therapy, and health outcomes in the Nurses'Health Study. Am J Public Health. 2016;106:1631-1637.

7. Mørch LS, Skovlund CW, Hannaford PC, Iversen L, Fielding S, Lidegaard Ø. Contemporary hormonal contraception and the risk of breast cancer. N Engl J Med. 2017;377:2228-2239.

8. Meshram II, Hiwarkar PA, Kulkarni PN. Reproductive risk factors for breast cancer: a case control study. Online J Health Allied Sci. 2009;8:1-4.

9. Pakseresht S, Ingle GK, Bahadur AK, Ramteke VK, Singh MM, Garg S, et al. Risk factors with breast cancer among women in Delhi. Indian J Cancer. 2009;46:132-138.

10. Lodha SR, Nandeshwara S, Pal KD. Risk of breast cancer in obese women: a case control study. Natl J Community Med. 2010;1:166-167.

11. Joseph DA, King JB, Miller JW, Richardson LC; Centers for Disease Control and Prevention (CDC). Prevalence of colorectal cancer screening among adults--behavioral risk factor surveillance system, United States, 2010. MMWR Suppl. 2012;61:51-56.

12. Alwan NA. Breast cancer: demographic characteristics and clinico-pathological presentation of patients in Iraq. East Mediterr Health J. 2010;16:1159-1164.

13. Lafta RK, Saeed EQ, Isa SA. Risk factors of breast cancer among women (A Sample from Baghdad). Iraqi J Commun Med. 2013;26:1-6.

14. Ghiasvand R, Maram ES, Tahmasebi S, Tabatabaee SH.Risk factors for breast cancer among young women in Southern Iran. Int. J. Cancer. 2011;129:1443-1449

15. Essiben F, Foumane P, Meka ENU, Soh PS, Sama,JD Osogo E, et al. Risk factors for breast cancer: a case-control study of 315 women followed in the gynecology and oncology departments of two university teaching hospitals in Yaounde, Cameroon. Open J Obstet Gynecol. 2016:6:676-688
16. Robbins SL, Cotran RS, Kumar V.Pocket Companion: Pathologic Basis of Disease. $2^{\text {nd }}$ Ed.: WB Saunders Co, Philadelphia, USA, 2001.

17. International Agency for Research on Cancer./ARC Hand-books of Cancer Prevention. Weight Control and Physical Activity. Vol 6, IARC Press, France,2002.

18. Altaha MA, Al-ani. Reproductive factors and risk of breast cancer. Al-Anbar Med J. 2013:11:17-26.

19. Nkondjock A, Ghadirian P. [Risk factors and risk reduction of breast cancer] Med Sci (Paris).2005;21:175-180 (in French).

20. Alwan NAS. Family history among Iraqi patients diagnosed with breast cancer. Int J Sci Res. 2017;6:869-873.

21. Butt Z, Shahbaz U,Naseem T,Ashfaq U,Khan UA, Khan MR, et al.Reproductive risk factors for female breast cancer: a case - control study. Ann King Edw Med Univ. 2009;15:206-210.

22. Mahouri K, Dehghani Zahedani M, Zare S. Breast cancer risk factors in south of Islamic Republic of Iran: a case-control study.East Mediterr Health J. 2007;13:1265-1273

23. Graham AC, Heather JB, Rulla MT. Breast cancer. In: David S, Joseph FF (eds.) Cancer Epidemiology and Prevention, $3^{\text {rd }}$ Ed.; Oxford University Press Inc., New York, 2006, pp. 995-1012.

24. Sahan ES, Majid AY, Hassan AS. Evaluation of estradiol and prolactin serum levels "in premenopausal; and postmenopausal" women with ((breast cancer)) in Baghdad city. Iraqi Natl J Nurs Spec. 2017;30:111-117.

25. Breast cancer and hormone replacement therapy: collaborative reanalysis of data from 51 epidemiological studies of 52,705 women with breast cancer and 108,411 women without breast cancer Collaborative Group on Hormonal Factors in Breast Cancer. Lancet 1997; 350:1047-1059.

26. Laamiri FZ, Bouayad A, Hasswane N, Ahid S, Mrabet M, Amina B.Risk factors for breast cancer of different age groups: Moroccan data? Open J Obstet Gynecol. 2015;5:79-87.

27. Khalis M, Charbotel B, Chajès V, Rinaldi S, Moskal A, Biessy C, et al. Menstrual and reproductive factors and risk of breast cancer: A case-control study in the Fez region, Morocco. PLoS One 2018;13:e0191333.

28. Al-Ramahi S.J.J, Al-Saffar AJAA. Breast Cancer Risk Factors among Iraqi Women from Baghdad/Iraq 2012. Published Thesis, The Arab Board in Community Medicine,2013, 37.

29. Bahir BH, Al-Naqeeb AA., Niazy SM. Risk factors for breast cancer in a sample of women. Iraqi J. Commun. Med.2012;25:4-8.

30. Wang QS, Ross RK, Yu MC, Ning JP, Henderson BE, Kimm HT. A case-control study of breast cancer in Tianjin, China. Cancer Epidemiol Biomarkers Prev. 1992:1:435-439. 
31. Kumle M, Weiderpass E, Braaten T, Persson I, Adami HO, Lund E. Use of oral contraceptives and breast cancer risk: the Norwegian- Swedish women's lifestyle and health cohort study. Cancer Epidemiol Biomarkers Prev. 2002; 11:1375-1381.

32. Norsa'adah B, Rusli BN, Imran AK, Naing I, Winn T. Risk factors of breast cancer in women in Kelantan, Malaysia. Singapore Med J. 2005:46:698-705.

33. Balekouzou A, Yin P, Pamatika CM, Bekolo CE, Nambei SW, Djeintote M, et al.Reproductive risk factors associated with breast cancer in women in Bangui: a case-control study. BMC Womens Health. 2017;17:14

34. Terry KL, Willett WC, Rich-Edwards JW, Hunter DJ, Michels KB. Menstrual cycle characteristics and incidence of premenopausal breast cancer Cancer Epidemiol Biomarkers Prev.2005;14:1509-1513.

35. Grabrick DM, Vierkant RA, Anderson KE, Cerhan JR, Anderson VE, Seller TA. Association of correlates of endogenous hormonal exposure with breast cancer risk in 426 families (United States). Cancer Causes Control. 2002;13:333-341.

36. Gao YT, Shu XO, Dai Q, Potter JD, Brinton LA, Wen W, et al. Association of menstrual and reproductive factors with breast cancer risk: results from the Shanghai Breast Cancer Study. Int J Cancer. 2000;87:295-300.

37. Clavel-Chapelon F. Cumulative number of menstrual cycles and breast cancer risk: results from the E3N cohort study of French women. Cancer Causes Control. 2002;13:831-838.
38. den Tonkelaar I, de Waard F. Regularity and length of menstrual cycles in women aged 41-46 in relation to breast cancer risk: results from the DOMproject. Breast Cancer Res Treat. 1996;38:253-258.

39. Wu AH, Ziegler RG, Pike MC, Nomura AM, West DW, Kolonel LN, et al. Menstrual and reproductive factors and risk of breast cancer in AsianAmericans. Br J Cancer. 1996;73:680-686.

40. Parazzini F, La Vecchia C, Negri E, Franceschi S, Tozzi L. Lifelong menstrual patterns and risk of breast cancer. Oncology. 1993;1993:222-250.

41. Titus-Ernstoff L, Longnecker MP, Newcomb PA, Dain B, Greenberg ER, Mittendorf $\mathrm{R}$, et al. Menstrual factors in relation to breast cancer risk. Cancer Epidemiol Biomarkers Prev. 1998;7:783-789.

42. Collaborative Group on Hormonal Factors in Breast Cancer. Familial breast cancer: collaborative reanalysis of data from 52 epidemiological studies of 58209 women with breast cancer and 101986 women without the disease. Lancet. 2001;358:1389-1399.

43. Brewer HR, Jones ME, Schoemaker MJ, Ashworth A, Swerdlow AJ. Family history and risk of breast cancer: an analysis accounting for family structure. Breast Cancer Res Treat.2017;165:193-200.

44. Ford D, Easton DF, Peto J. Estimates of the gene frequency of BRCA1 and its contribution to breast and ovarian cancer incidence.Am J Hum Genet. 1995;57:1457-1462. 